\title{
EXPLORING THE STUDENTS' EXPERIENCE IN LEARNING LITERATURE: CHALLENGES OF CONTEXTUALIZATION
}

\author{
Jennifer D. Suganob ${ }^{1}$, Elleine Rose A. Oliva ${ }^{2}$
}

Article DOI: https://doi.org/10.36713/epra9033

DOI No: 10.36713/epra9033

\begin{abstract}
This qualitative-phenomenological study aimed to explore the lived experiences of the Senior High School students in region 11, particularly their learning experience in contextualizing literature. This inquiry was gleaned from Vygotsky, Brunner, and Dewey (1997). Employing the sampling technique, snowball sampling, five (5) students were selected for the in-depth interview. Another five (5) students were selected for the focus group discussion with ten (10) students from five regions' schools. As to the participants' lived experiences in learning literature, the following four (4) significant themes emerged: Enjoying the familiarity of content, participating in discussions, developing knowledge expansion, and using familiar examples as learning guides. For the students' perspective in situations that influence the challenges in contextualization, the following five (5) majors emerged: Listening carefully to the teacher, participating actively during classwork, acquiring lifelong lessons, giving participation opportunities for community-based programs, and employing teaching materials. Finally, the students' perspectives on overcoming contextualization issues were organized into three (3) primary themes. Improved knowledge through contextualization, effectively employing contextualization and learning to study well. The findings of this study are essential for academic institutions to comprehend students' contextualization experiences.
\end{abstract}

KEYWORDS:Contextualization, qualitative phenomenological study, thematic analysis, region 11, Philippines

\section{INTRODUCTION}

Contextualization is seen as a breakthrough in language and literary education. In the K-12 curriculum, this technique is given due weight and priority. The in-depth comprehension of Philippine literature is one of the primary issues in the Filipino subject.

Ambrose (2013) discovered that utilizing contextualization to teach literature had no significant effect on the quality of the students' learning in a study done in California. In research done in the United States, Svinicki (2004) rejected this, noting that contextualization requires adequate time, preparation, and exposure to understand the issue stated. Najman (2007) of the Philippines' Cordillera Region pointed out that the biggest issue for pupils today is understanding literature through contextualization. The issue would develop due to a scarcity of authentic local literary works that kids may relate to. Problems with the use of contextualization may be revealed as a consequence of this study, with the results providing answers, techniques, and approaches for instructors to use in the classroom.

\section{OBJECTIVES}

The primary purpose of this study is to unravel the lived experience of the students in using contextualization for teaching literature. The study results may vastly impact the efficient use of contextualization in teaching literature.

\section{METHODS}

This research used a qualitative design and took a phenomenological approach. Furthermore, the Phenomenological technique is a philosophical and psychological investigation in which the researcher describes individuals' lived experiences with a phenomenon as stated by participants (Creswell, 2016).

The participants in this study were students from the first class of K-12 curriculum graduates. Furthermore, the participants in this study were chosen 
using the snowball sampling technique, which used inclusion criteria. The following standards were established: (a) The learner enrolled in a Filipino subject in the academic year 2020-2021; (b) the learner is a student at a private school in the Davao Region, and (c) the student is a "21st-century learner" and a millennial.

Qualitative interviews were the primary source of data for this qualitative-phenomenology investigation. During the study, in-depth interviews
(IDI) with five (5) participants and focus group (FGD) interviews with a group of five (5) interviewees were used as types of data sources in qualitative inquiry. The data-gathering technique was conducted with a total of ten (10) participants. The methods for gathering trustworthy and rich data for results and discussion were in-depth interviews (IDI) and focus group discussions (FGD).

\section{RESULTS AND DISCUSSION}

Table 1

The Major Themes and Core Ideas on the Lived Experiences of the Students in Learning Literature amidst the Challenges of Contextualization

\begin{tabular}{|c|c|}
\hline Major Themes & Core Ideas \\
\hline Enjoying the Familiarity of Content & $\begin{array}{l}\text { - Discussing frequently familiar lessons. } \\
\text { - } \quad \text { Enjoying the standard examples used in class. } \\
\text { - Being interested in group activities due to the } \\
\text { familiarity of the lesson }\end{array}$ \\
\hline Participating in Discussions & $\begin{array}{ll} & \text { Sharing insights to answer the questions } \\
\text { - } & \text { Expressing experiences connected to the topic } \\
\text { - } & \text { Participating actively and voluntarily }\end{array}$ \\
\hline Developing Knowledge Expansion & $\begin{array}{l}\text { - Having increased prior knowledge } \\
\text { - Providing information about places and } \\
\text { societal events } \\
\text { - Understanding, increasing and expanding prior } \\
\text { knowledge well }\end{array}$ \\
\hline Using Familiar Examples as Learning Guides & $\begin{array}{l}\text { - Utilizing examples } \\
\text { - Discussing familiar examples during lesson } \\
\text { proper } \\
\text { - Contextualizing examples in conjunction with } \\
\text { the Philippines }\end{array}$ \\
\hline
\end{tabular}

\section{Lived Experiences of Students in Learning Literature amidst the Challenges of Contextualization}

As accumulated in the responses of the participants, the following were the major themes that emerged: (1) Enjoying the familiarity of content, (2) participating in discussions, (3) developing knowledge expansion, and (4) using familiar examples as learning guides.

\section{Enjoying the Familiarity of Content}

Contextualization is essential in language instruction, according to Perin (2011). As a result, most teachers feel that adopting contextualization in teaching a language-based subject has a good impact. The key benefit of this method is that it can hold students' attention while also familiarizing them with the lecture topic. Puncher and Taylor (2006) were both on board with this idea. When contextualization was used in the study, most of the students felt motivated and engaged in properly completing the course. Furthermore, the component of contextualization, in which students can tie their understanding of the literary piece to a relevant human experience, piques their interest.

\section{Participating in Discussion}

Cordova and Lepper (1996) highlight the importance of this issue by stating that interaction is necessary for the teaching-learning process. Students can contribute their ideas and are given a more accessible platform to understand the message portrayed in the learning material attributable to the 
interaction provided by contextualization. Furthermore, according to Leiva and Alabau (2014), one of the pillars in actualizing what students learn is to use various ways to address the students' learning needs. This can be accomplished by students actively participating in conversations.

\section{Developing Knowledge Expansion}

Hartree (1984), using the notion of Malcolm Knowles Theory of Andragogy or Adult Learning Theory, expands on the significance of this theme. According to this notion, adult learners have a different method of collecting information than youthful learners. Adult learners can engage in self-learning

Table 2

The Major Themes and Core Ideas on the Situations that Influence the Experiences of the Students amidst the Challenges of Contextualization

\begin{tabular}{|c|c|}
\hline Major Themes & Core Ideas \\
\hline Listening Carefully to the Teacher & $\begin{array}{l}\text { - Interacting well during discussions. } \\
\text { - Listening carefully, especially during } \\
\text { complex topics. } \\
\text { - Providing examples relating to students' } \\
\text { experiences }\end{array}$ \\
\hline Participating Actively during Classwork & $\begin{array}{l}\text { - Joining enthusiastically when the questions } \\
\text { are related to the students' experiences. } \\
\text { - Participating in training and programs } \\
\text { - Showing interest in joining classroom } \\
\text { activities }\end{array}$ \\
\hline Acquiring Life-long Lessons & $\begin{array}{ll}\text { - } & \text { Relating examples in real-life experiences } \\
\text { - } & \text { Providing activities related to recent events } \\
\text { - } & \text { Bringing an insightful message to the students } \\
\text { of what to do and not to do. }\end{array}$ \\
\hline $\begin{array}{l}\text { Giving of Participation Opportunities for Community- } \\
\text { based Programs }\end{array}$ & $\begin{array}{l}\text { - Participating in studies and exercises related } \\
\text { to the subject matter. } \\
\text { - Having students learn faster. } \\
\text { - Actively partaking in social activities, } \\
\text { especially in school. }\end{array}$ \\
\hline Employing Teaching Materials & $\begin{array}{l}\text { Using different teaching tools. } \\
\text { - Utilizing modern technology like a projector } \\
\text { to teach efficiently. }\end{array}$ \\
\hline
\end{tabular}

\section{The Situations that Influence the Experiences of the Students amidst the Challenges of Contextualization}

As cited in the responses of the participants, the following were the major themes that emerged: (1) Listening carefully to the teacher, (2) participating actively during classwork, (3) acquiring life-long lessons, (4) giving of participation opportunities for community-based programs, and (5) employing teaching materials. more effectively, according to this theory. Ghefaili (2003) readily supports this approach, stating that gaining experience connected to the lesson allows the learner to understand the issue.

\section{Using Familiar Examples as Learning Guides}

The students' familiarity with the elaborations during the class is a valuable method for instilling understanding. According to Wisely (2009), using examples effectively presents a topic to the learner. Using real-life and hypothetical thinking circumstances is vital in developing students' abilities to visualize, conceive, and think critically. are related to the students' experiences.

- Participating in training and programs

- Relating examples in real-life experiences

- Providing activities related to recent events of what to do and not to do. to the subject matter.

faster especially in school.

Using different teaching tools. to teach efficiently.

\section{Listening Carefully to the Teacher}

Foley (2005) establishes this subject as significant, stating that listening to the teacher during contextualized studies is critical to learning broad concepts. As a result, contextualization as a tactic is based on various pedagogical philosophies. Motivational, social-learning, problem-centered, and psychological theories are examples of such theories. When used effectively in the teaching-learning process, contextualization can speed up the acquisition of 
information. This is because it has to do with how a student's cognitive components link real-life experiences to abstract notions to produce meaning. As a result, contextualization allows for a more focused and critical approach to learning concepts (Redman, 2018).

\section{Participating Actively during Classwork}

Comprehensive research confirms the outstanding effects of adopting contextualization in teaching, according to Son and Goldstone (2009). For starters, this technique is designed to assist pupils in adding more knowledge in areas where they are lacking. Furthermore, actively participating in assignments might help students practice navigating through their daily activities and routine.

\section{Acquiring life-long lessons}

Brown (2009) established the importance of this issue by stating that contextualization can lead to lifelong learning. This is true because students learn more effectively when the subject is closely tied to their interests and experiences. Furthermore, according to Barnett (2016), respecting the county's cultural and educational heritage can help children comprehend their own identity. As a result, students are allowed to learn about their cultural identity. They are also urged to follow it throughout their lives.

\section{Giving of Participation Opportunities for Community-based Programs}

Brooks and Magnusson (2006) emphasized the importance of this concept by stating that when students recognize the relevance of what they have studied, they are more engaged. Learners can perform better when they understand the societal implications of an activity. The Buwan ng Wika is an example of this (Month of the Filipino Language). Through this event, learners are allowed to commemorate their linguistic and cultural heritage as Filipinos. Penny-Dahlstarnd, et al. (2013) backed up this claim by stating that students are more likely to participate in a program if they can connect the activity to what they've learned. Subjectoriented academic programs are encouraged and used to teach values and virtues.

\section{Employing Teaching Materials.}

During conversations, learning materials strengthen the bond between the teacher and the student. The quality of learning is improved when the instructor effectively uses technology in the classroom. According to Halperm (1999), including any innovation in the teaching-learning process can improve students' comprehension and involvement rates. According to Krebt (2017), when technology is effortlessly integrated into talks, it helps pique students' interest in understanding the subject matter. The more engaged the students are, the more enjoyable and livelier the discussion

Table 3

The Major Themes and Core Ideas on how the students overcame the Challenges of Contextualization in Learning Literature

\begin{tabular}{|c|c|}
\hline $\begin{array}{c}\text { Major Themes } \\
\end{array}$ & $\begin{array}{l}\text { Core Ideas } \\
\end{array}$ \\
\hline Enhancing Understanding through Contextualization & $\begin{array}{l}\text { - Expanding linguistic and cultural knowledge. } \\
\text { - Increasing students' understanding. } \\
\text { - Understanding the society better. }\end{array}$ \\
\hline Using Contextualization Effectively & $\begin{array}{l}\text { - Learning better-using contextualization } \\
\text { - Using contextualization as means to continually } \\
\text { teach literature } \\
\text { - Making learning lessons easy and efficient }\end{array}$ \\
\hline Learning to Study Well & $\begin{array}{l}\text { - Having students to study hard. } \\
\text { - Sharing learned experiences in language, } \\
\text { literature, and societal topics. } \\
\text { - Engaging in self-study without the teachers' } \\
\text { assistance. } \\
\text { - Using contextualization as means to change } \\
\text { perspectives in teaching and learning. }\end{array}$ \\
\hline
\end{tabular}




\section{The Students' Insights on How they overcame the Challenges of Contextualization in Learning Literature}

As reflected in the responses of the participants, the following were the major themes that emerged: (1) Enhancing understanding through contextualization, (2) using contextualization effectively, and (3) learning to study well.

\section{Enhancing Understanding through Contextualization}

Norman et al. (2013) expressed that contextualization gives meaning to the active research process connecting meaning-making, experience, and learning. Furthermore, Wyatt (2016) added that cultural contextualization is deemed vital in the students' appreciation and in-depth understanding of their cultural heritage. Thus, teachers are expected to relate and contextualize concepts and subject matters to foster a connection between the students and the literary piece.

\section{Using Contextualization Effectively}

According to Deggs (2011), contextualization as an approach has been shown to offer significant benefits in the teaching-learning process. One of these is allowing students to develop sharp perception and critical thinking skills. In addition, there is a strong link between abstract comprehension and contextualization. This indicates that the method positively impacts the student's learning quality.

Drira (2011) agreed, stating that contextualized courses and subjects serve as a training group for learners to develop a more profound interest in learning in general. This newfound motivation may inspire them to further lengths to improve their academic performance.

\section{Learning to Study Well}

According to Johnson (2013), contextualization is a deep understanding that demands a person to integrate their intellect, beliefs, and discipline. Contextualization is essential in the teaching-learning process because it encourages students to learn effectively and autonomously. As a result, teachers are strongly advised to employ this method when using real-life scenarios to stimulate students to understand the subject being taught. Perin (2011) also emphasized that students must see the connection between their academic learning and their daily life.

\section{SUGGESTION}

The limitations of using contextualization are solved by unraveling the students' input in this study, which is beneficial for teachers. Teachers might go over their teaching strategies and approaches again to see which ones produce the best results.

The study's findings can be used to develop a program that incorporates contextualization to the teaching of literature. Students may benefit from the program to improve their linguistic skills and critical thinking abilities. While the feedback and experiences of the students are essential in addressing their requirements, the teacher is encouraged to persevere through the difficulties and triumphantly overcome them to meet the students' demands.

It is also suggested that authentic and regional literary pieces be included in instructional materials for both private and public institutions. Compared to westernized narratives, textbooks, worksheets, and workbooks that are interwoven with the students' cultural heritage be more successful resources. Finally, the study may open the way for future researchers who want to look into the issue of contextualization.

\section{CONCLUSION}

Students and teachers must overcome hurdles when using contextualization as an approach. To guarantee that students are familiar with topics, authentic and localized materials must be used when teaching literature. Furthermore, through localizing literary works, teachers have the opportunity to connect students to the heart of the work. Once the context is defined, topics are approachable, and students can draw on their meaningful human experience, life-long learning becomes a reality.

\section{REFERENCES}

1. Ambrose, V. K., Davis, C. A., \& Ziegler, M. F. (2013). A framework of contextualized teaching and learning: Assisting developmental education instructors

2. Barnett, J. L. (2016). Toward the needs for the contextualization of curriculum for Native American Baptist churches in Oklahoma. Southeastern Baptist Theological Seminary.

3. Brown, R., Fish, B., Travis, J., Adams, E., \& Allen, D. (2009). Movements and Contextualization: Is There Really a Correlation. International Journal of Frontier Missiology, 26(1), 21-23.

4. Cordova, D. I., \& Lepper, M. R. (1996). Intrinsic motivation and the process of learning: Beneficial effects of contextualization, personalization, and choice. Journal of educational psychology, 88(4), 715.

5. Creswell, J. W., \& Poth, C. N. (2016). Qualitative inquiry and research design: Choosing among five approaches. Sage publications.

6. Deggs, D. (2011). Contextualizing the Perceived Barriers of Adult Learners in an Accelerated 
Undergraduate Degree Program. Qualitative Report, 16(6), 1540-1553.

7. Drira, R., Laroussi, M., Le Pallec, X., \& Warin, B. (2011). Contextualizing learning scenarios according to different learning management systems. IEEE Transactions on Learning Technologies, 5(3), 213-225.

8. Foley, J. A., \& McAllister, G. (2005). Making it real: Sim-school a backdrop for contextualizing teacher preparation. AACE Journal, 13(2), 159177.

9. Ghefaili, A. (2003). Cognitive apprenticeship, technology, and the contextualization of learning environments. Journal of Educational Computing, Design \& Online Learning, 4(1), 1-27.

10. Halpern, D. F. (1999). Teaching for critical thinking: Helping college students develop the skills and dispositions of a critical thinker. New directions for teaching and learning, 1999(80), 6974.

11. Hartree, A. (1984). Malcolm Knowles' theory of andragogy: A critique. International journal of lifelong education, 3(3), 203-210

12. Krebt, D. M. (2017). The effectiveness of role play techniques in teaching speaking for EFL college students. Journal of Language Teaching and Research, 8(5), 863

13. Johnson, A. M., Butcher, K. R., Ozogul, G., \& Reisslein, M. (2013). Introductory circuit analysis learning from abstract and contextualized circuit representations: Effects of diagram labels. IEEE Transactions on Education, 57(3), 160-168.

14. Leiva, L. A., \& Alabau, V. (2014, April). The impact of visual contextualization on ui localization. In Proceedings of the SIGCHI Conference on Human Factors in Computing Systems (pp. 37393742).

15. Najman, H. (2007). How should we contextualize pseudepigrapha? Imitation and emulation in 4 Ezra. In Flores Florentino (pp. 529-536). Brill.

16. Normann, B., Sørgaard, K. W., Salvesen, R., \& Moe, S. (2013). Contextualized perceptions of movement as a source of expanded insight: People with multiple sclerosis' experience with physiotherapy. Physiotherapy theory and practice, 29(1), 19-30.

17. Peny-Dahlstrand, M., Krumlinde-Sundholm, L., \& Gosman-Hedstrom, G. (2013). Patterns of participation in school-related activities and settings in children with spina bifida. Disability and rehabilitation, 35(21), 1821-1827.

18. Perin, D. (2011). Facilitating student learning through contextualization: A review of evidence. Community College Review, 39(3), 268295.

19. Puchner, L. D., \& Taylor, A. R. (2006). Lesson study, collaboration and teacher efficacy: Stories from two school-based math lesson study groups. Teaching and teacher education, 22(7), 922-934.
20. Redman, E., Wiek, A., \& Redman, A. (2018). Continuing professional development in sustainability education for $K-12$ teachers: principles, programme, applications, outlook. Journal of Education for Sustainable Development, 12(1), 59-80.

21. Son, J. Y., \& Goldstone, R. L. (2009). Contextualization in perspective. Cognition and Instruction, 27(1), 51-89.

22. Svinicki, M. D. (2004). Learning and motivation in the postsecondary classroom. Anker Publishing Company.

23. Wiseley, W. C. (2009). Effectiveness of contextual approaches to developmental math in California community colleges. University of the Pacific.

24. Wyatt, T. R. (2016). Contextualization strategies for implementation of the common core. Issues in Teacher Education, 25(2), 117. 